\title{
Provision of Quality Basic Education for All in Kenya: Post 2015 Agenda
}

\author{
Brenda S. Khanani \\ Department of Educational Foundations, Masinde Muliro University of Science and Technology
}

\begin{abstract}
Education plays a critical role in the development of any society. It is for this reason that the World Conference held in Jomtien Thailand in 1990 came up with Education for All (EFA) declaration. This followed the realization that quality basic education was important for the success of human endeavors. It is for this reason that the Dakar Forum and the MDGs set EFA by 2015. Against this background, Kenya introduced Free Primary Education (FPE) in 2003 and this led to an increase in enrolment. However, increasing access to primary education doesn't necessarily prove valuable unless it is seen as a promising path for individuals to realize better, more productive lives and as a driver of national economic development. This paper argues that such access to primary education should go hand in hand with quality. Recent policy documents such as Sessional Paper Number 14 of 2012 and Basic Education Act 2013 spell out the government's commitment to provision of quality basic education for all citizens. However, studies reveal that the quality of basic education in the country remains far below the expected standards. Getting children through primary schools will not be enough. While education is central to the country's agenda and noticeable achievements have been made in the context of EFA, significant challenges remain. There are vast disparities within the country as concerns access to schooling and the quality of education in resulting levels of learning achievement. The post 2015 agenda in Kenya therefore should take into account that achieving EFA remains a key yet unfinished agenda for basic education in the country, requiring strengthened efforts in order to meet its goals. Therefore, future orientations for education require a widening of the EFA agenda in response to current development trends of the Kenyan nation. This paper focuses on provision of quality basic education.
\end{abstract}

Key Words: Free Primary Education, Education for All, Quality basic Education

\section{INTRODUCTION}

$\mathrm{E}$ ducation is a vital component in human development. It is for these reason that many countries the world over continue to invest heavily in the provision of quality education to their citizens. Kenya is no exception to this norm and that is why it spends about $7 \%$ of its gross domestic product (GDP) on the education sector. This clearly shows the kind of interest and importance that the country attaches to the development of education and human resource in general. It is therefore not surprising that the education sector receives serious scrutiny from different quarters if just to assure on the expected returns.

Despite impressive performance in terms of access, there is a growing concern regarding quality of education and learning outcomes. This has come as a result of the realization that the quality of basic education in the Kenya continues to decline partly due to massive educational expansion since 2003 following the implementation of the free primary education (FPE) programme. While FPEhas increased access to primary education especially among poorer households, the provision of quality education remains a challenge. Success or failure of achieving the goal of education for all (EFA) hinges critically not just on the country providing access to education or delivering more years of schooling but ultimately what children learn and the quality of their education experience. Empirical studies provide robust evidence that quality education contributes to economic growth and that learning rather than schooling, has a direct impact on growth and development (Okwach and Abagi, 2005).

In shaping education for the future therefore, efforts to expand enrolment at all levels must be accompanied by policies to enhance the quality of that education. Quality education and learning therefore should be one of the key areas of focus in the development of education for the future and the post 2015 agenda in Kenya.

This paper examines the provision of basic education in Kenya since independence with specific focus on quality. We start by making a justification for provision of basic education before examining Kenya's past initiatives at increasing access with their attendant impact on quality. This is then followed by an examination of the present situation and policies that the government is putting in place and how this is likely to influence the agenda for providing quality education in the post 2015 period.

\section{RATIONALE FOR PROVISION OF BASIC EDUCATION IN KENYA}

The importance of education in development the world over cannot be overemphasized. It is for this reason that the provision of education by African countries soon after independence was seen as an important means to socioeconomic and political development. Education to the new governments offered an opportunity of forging national unity and reducing inequalities that were so visible during the colonial period. By 1963, formal education had become a central issue in the country's political agenda since the colonial and missionary literacy programmes only benefitted a small African minority and therefore failed to meet the universal threshold. The African nationalists did not take this matter lightly. For example, Kenya African Union (KAU) had demanded the provision of free primary education for 
Africans as early as the 1940s. Accordingly, the expansion of educational opportunities was seen as an important responsibility of the government in independent Kenya (Cooksey, B. Court, D and Makau, B. 1994).

The impetus towards this initiative came from the resolutions of the Conference of African states on the development of education in Africa held in Addis Ababa in May 1961. The Conference, among other things deliberated on the provision of basic education with participants committing themselves to the provision of universal primary education (UPE) by 1980 (Sifuna and Otiende, 1994). It is this thinking that informed the Kenya African National Union (KANU) manifesto of 1963 which promised seven years of free universal primary education on the basis that meaningful development of the country could only be achieved with an educated population.

The drive towards universal education on the African continent at the time especially at the basic level should be seen in the light of the United Nation's Universal Declaration of Human Rights and the Declaration of the Rights of the Child issued in 1948 and 1959 respectively which called for the provision of free and compulsory elementary education on the justification that education moulds the learners into rational thinkers and promotes change agents within their social milieu. This was re-iterated in other key documents that followed including the 1989 Convention on the Rights of the Child which made education a basic and compulsory right for every individual (Achola and Pillai, 2000).

Investing in education is critical as its benefits carry a direct relationship to both human and national development. A well educated population will participate actively in initiating, sustaining and accelerating social and economic development through higher labour productivity and enhanced partnerships in the processes of development (World Bank, 2000; Achola and Pillai, 2000). The primarylevel of schooling is critical in educational processes as it forms the foundation on which future learning activities are built. The pedagogical influence at the primary level introduces the learner to reading habits and intellectual curiosity. Primary education has also been shown to yield higher rates of return necessary for human survival than what is provided at secondary and tertiary levels (Achola and Pillai, 2000). It is for this reason that the Kenyan government continues to invest heavily in primary education. Accordingly, developing countries, Kenya included, ought to put greater emphasis on the provision of basic education for purposes of achieving broader developmental befits for their people.

\section{PAST INITIATIVES AND THEIR EFFECTS ON THE PROVISION OF QUALITY EDUCATION}

As the MDGs come to an end in 2015 and the world start focusing on the direction education has to take in the future, there is need to highlight some of the initiatives by the government of Kenya in addressing the whole question of EFA and how this has impacted on the provision of quality education. Informed by the resolutions arrived at Addis Ababa
Conference among others, the government of Kenya gave full support to the objective of giving every child a minimum of seven years free primary education starting in 1965 to be completed in 1971(RoK, 1964/65). However, economic priorities at the time forced the government to pay urgent attention to post-primary education to develop the much needed middle and high level, skilled and professional manpower for the africanization programme. Consequently UPE was seen as a long term rather than an immediate goal of education (RoK, 1964/65).

Efforts towards the realization of UPE were re-ignited by the Presidential decree of December 1973 which abolished the payment of tuition fees for the first four years of primary schooling in the whole country from 1974. This single move increased enrolment in primary schools from 1.8 million pupils in 1973 to 2.8 million pupils in 1974. The extension of free primary education to the remaining classes (standard 5-7) by 1980 again saw enrolment increase to over 4.3 million pupils by 1983 (Bogonko, 1992: Sifuna \& Otiende, 1994).

While these efforts towards UPE in the 1970s were impressive, they created other challenges that impacted negatively on the quality of education. For example, the shortage of teachers to attend to increased enrolment necessitated the employment of untrained teachers which affected the quality of education. The ratio of trained to untrained teachers fell from 4:1in 1970 to $2: 1$ after the 1973 decree period. Untrained teachers constituted $1 / 3$ of the teaching force by 1980 and stood at 47,270 to 108,424 trained teachers in 1988. The move also led to a shortage of physical facilities (classrooms and books).For example, standard one enrolment increased by $153 \%$ from 379,370 in 1973 to 958,980 in 1974 . The congestion that followed the big increase forced pupils to learn under trees while in other parts of the country learning was carried out in shifts which impacted negatively on the quality of education.

As early as 1975, the government had realized that the education being offered was deficient in quality. The curriculum was viewed as being too academic, narrow and examination centered (Republic of Kenya, 1979b; Republic of Kenya 1980). During the first two decades of independence, reforms in curriculum played a pivotal role in directing the expected quality of education in Kenya. Major innovations were introduced in the curriculum namely: the new mathematics, agricultural, industrial and science education Project for Africa (SEPA), the SPP Nuffield-based science programmes, the New Primary approach among others (Eshiwani, 1993). These efforts unfortunately did not bring about the desired quality in the education system. The reforms failed to respond to the problems of low quality curriculum materials, irrelevant content and inappropriate instructional approaches and contributed decimally to development.

In the 1980s the government changed its policy on education. This was because of the difficulties which were being faced by graduates of its education system at both primary and secondary levels. Most graduates who were matriculating 
from these levels could not be absorbed into the shrinking labor market. This made the government to consider changing its education system leading to the current 8-4-4 education system. However, this system has faced numerous challenges right from its inception such as lack of infrastructure like classrooms and workshops, trained personnel and funds with devastating effects on quality of basic education (Sifuna, 1990).

The efforts aimed at reforming the system to realize quality education for its citizens were undermined by donor induced economic policies especially the structural adjustment programmes (SAPs). This followed the economic crisis that hit many African countries following the oil shocks of the 1970s which forced them to borrow heavily from other countries and multilateral banks to service their debts. By 1980s, the debts had become unsustainable making the donor agencies such as the World Bank and the International Monetary Fund to force these countries to implement a set of economic reforms to ensure they had money to continue servicing their debt obligations and avoid a large scale global debt default. To realize this, most of third world countries, Kenya included cut back on their social spending including education (Sifuna \& Oanda, 2014).

The difficulties encounteredin financing of education programmes following the introduction of SAPs and their emphasis on strict fiscal discipline led the Kamunge Report of 1988 and the subsequent Sessional Paper No.6 of 1988 to propose cost-sharing in education. (RoK, 1988 a; b). This policy led to devastating effects on the provision of education. Households were now required to meet about $95 \%$ of the schools' recurrent expenditure. The failure by many families to meet their obligations led to the non-enrolment of many eligible children and high drop-out rates. The country experienced declining GERs at primary school level from 1990. For instance, the gross enrolment rate (GER) dropped from $95 \%$ in 1989 to $75.9 \%$ in 1998 (6-14 cohort) while the net enrolment rate (NER) stood at $67 \%$. The quality of education was not spared either and continued to deteriorate due to lack of learning and teaching materials and also lack of enough teachers (GoK, 1999). The Country's commitments towards the realization of its national and international obligations in education, specifically EFA has never been so bleak.

A new optimism was however reignited in 2003 with the government's free primary education (FPE) initiative that abolished tuition fees and other levies for primary education. Unfortunately the hurried manner with which FPE was implemented without proper planning occasioned unprecedented congestion in schools. It was estimated that 1.8 of eligible primary school pupils previously out of school were enrolled during the first year of the programme. Apart from overcrowding, quality was affected by the inadequate supply of teachers. The need to regulate the high salary bill for the ministry forced the government only to replace teachers who leave through death, resignation or retirement. The challenge has been how to balance the cost of teachers, and the recurrent budget vis-à-vis the need for more teachers for increased number of children in schools and provision of quality education.

Although the government has over the years come up with interventions to ensure as many children as possible benefit from basic education, the poor quality of this education continues to jeopardize the future of millions of young people in the country. This has been the case despite the Government's continued heavy investments in basic education. For instance, public spending in education in Kenya as a proportion of Gross Domestic Product (GDP) increased from $5.1 \%$ in $1980 / 1981$ to $7.05 \%$ in $2006 / 2007$ (World Bank, 2013).Despite these enormous efforts, the education enterprise continues to encounter serious challenges that have eroded quality. The education system has been accused of adopting irrelevant and rigid curricula, for embracing antiquated teaching and learning techniques, for dampening initiative and curiosity, for producing docile and dependent minded graduates, and for widening the gap between the rich and the poor.

\section{CURRENT STATUS}

The struggle by Kenya to increase educational opportunities for its citizens especially at the basic level has in recent years received support from the international protocols as well as national policy and legal frameworks. Some of these initiatives include:

- The United Nations sponsored Millennium Development Goals (MDGs) and Dakar Forum Declaration on attainment of education for all (EFA) by 2015 . As the MGDs come to end by 2015, the Government of Kenya is conscious of the fact that it can be said to have made good progress in achieving the two MDGs i.e. Universal Primary Education (UPE) and eliminating gender disparities in primary and secondary schools at all levels by 2015 .

- Free Primary Education (FPE) initiative in 2003 which set out to make primary education accessible and affordable to all children especially those previously excluded and disadvantaged groups. This saw an estimate of 1.8 million children previously out of school enroll and it marked a major milestone towards the realization of the EFA goal initially grafted in Jomtien, Thailand in 1990.

- The Government through Sessional Paper No. 1 of 2005, "Policy Framework for Education, Training and Research" reiterated its commitment to increasing educational opportunities for all Kenyans. This was later followed by Kenya's Education Sector Support Programme (KESSP), the single largest sector wide approach investment programme ever undertaken within the education sector.

- Kenya Vision 2030 set out ambitious goals for education which among others targeted 95 percent 
net enrolment by 2012, and education for all by 2015.

All these efforts have helped Kenya register tremendous increase in the number of children enrolled in primary schools. Impressive as it is, questions have been asked regarding the quality of this education. An assessment of FPE in 2005 established that the influx of children in schools that followed the implementation of this programme had had serious implications on the quality of teaching and learning in primary schools. The teachers were not able to give individual attention to the learners, especially to the slow ones, and this $\mathrm{m}$ a d e it difficult for schools to offer quality education. Whereas the provision of funds was seen as a step in the right direction in boosting the quality of education since children were being kept in school, it was however noted that quality had gone down due to large numbers of pupils in classes that made it difficult for the teachers to provide attention to all learners. For example, teachers were unable to give adequate assignments to the pupils as they could not cope with the marking and teaching workload (MoEST \& UNESCO, 2005).

Since the introduction of FPE in 2003, doubts about the quality of education has forced many parents including families that may not be so stable economically to transfer their children from public primary schools to private schools (academies)(MoEST \& UNESCO, 2005). This has been aimed at helping these children achieve good grades in the primary school examination and be able to compete for few places in good secondary schools in the country preferably national schools that have superior facilities. Interestingly, some of the so called academies have inferior facilities compared to those found in public schools. A situation where parents will prefer inferior facilities compared to some wellendowed primary schools not only raises serious questions regarding public perceptions about the quality of education but the future of their children as well.

Since 2009, an innovative research approach by Uwezo East Africa has established serious challenges regarding learning outcomes in our learning institutions. Based on the theory of social change, Uwezo has been assessing learning outcomes in the East African countries - Kenya, Uganda and Tanzania at the household level. The findings from these annual studies have consistently shown that education systems are not meeting the expectations of their clientele.

For example, assessments carried out in 2012 show that less than one third of children enrolled in class 3 proved that they had attained basic literacy and numeracy skills. It was further noted that two out of ten pupils enrolled in class 7 do not have class two literacy and numeracy competencies. The reports have consistently established since 2009 that children are not acquiring skills of literacy and numeracy consistent with official curricula requirements. This can partly be attributed to the chronic absenteeism by teachers in our schools where it was established that at least one teacher in ten is absent from school in any given day. These findings are a serious indictment of our education system in that attending school does not necessarily translate into any meaningful learning (Uwezo, 2014).

\section{FUTURE AGENDA- QUALITY EDUCATION BEYOND 2015}

The 2014 Global EFA meeting held in Oman in May called for "equitable and inclusive quality education and lifelong learning for all by 2030". This successfully informed the proposed education targets of the Open Working Group on Sustainable Development Goals (SDGs). The targets were adopted at the World Education Forum 2015 in Incheon; Republic of Korea held between 19 and 22 May 2015 and will now be included in the United Nations Charter to be signed in September 2015 as part of the SDGs for 2030. The Forum developed a new vision of education which is, "to transform lives through education, recognizing the important role of education as a main driver of development and in achieving the other proposed SDGs." This vision is well captured by the proposed SDG 4 "Ensure inclusive and equitable quality education and promote life-long learning opportunities for all". In the final declaration, the delegates pledged to focus their efforts on access, equity and inclusion, quality and learning outcomes.

It is clear that as we move towards 2030, apart from focusing on access to basic education, there will be need to take a serious look at quality of education to be offered to our children. Towards this end, delegates were categorical in stating that realizing quality education;

...requires strengthening inputs, processes and evaluation of outcomes and mechanisms to measure progress. We will ensure that teachers and educators are empowered, adequately recruited, well-trained, professionally qualified, motivated and supported within well-resourced, efficient and effectively governed systems [UNESCO, 2015].

Reflecting on the Forum's commitments, there is no doubt that the Constitution of Kenya adopted in August 2010 has already set the agenda for education for the post-2015 period. Apart from recognizing education as a basic human right, the Constitution offers a firm base for government commitment to education as well as extensive reforms in policy, legislation and curriculum (Sifuna \& Oanda, 2014). The Constitution commits the government to the provision of free and compulsory basic education to all school age children. Articles 43 (1) (f), 53 (1) (b) and 55 (a) in Chapter 4 of the Constitution obligates both the state and the parents to facilitate access to quality basic education by all children (RoK, 2010).

The government has also taken associated steps in developing legal frameworks purposely to align the education system in the country to the provisions of the Constitution. These include; Sessional Paper No. 14 of 2012 and the passing of the Basic Education Act 2013. The Act gives effect to Article 43(f) and 53(1) (b) of the Constitution to promote and regulate 
free and compulsory basic education. Section 28 is clear that every child has a right to free and compulsory basic education. Section 29 outlaws the charging of fees for the same while section 30 makes it a criminal offence for any parent or person who fails to take his or her child to school. Part IX of the Basic Education Act 2013, establishes the Education Standards and Quality Assurance Council (ESQAC) which among others has to: i) ensure standards and maintain quality in institutions of basic education; ii) administer policies and guidelines set for basic education; iii) supervise and oversee curriculum implementation and delivery and iv) monitor and evaluate standards and quality in basic education (RoK, 2013).

As we focus on the future, it will be important to take note of the challenges that bedevil our education system. The teaching profession will be critical in achieving quality education, a view well-articulated by at World Education Forum. A study carried out by Elimu Yetu Coalition in 2004 revealed that most primary schools in the country were faced with a shortage of teachers. In most schools, the teacher-pupil ratio is very high and this makes quality teaching difficult. According to World Bank 2015 statistics, the teacher-pupil ratio in primary schools in Kenya currently stands at 1:57. Some studies have also shown that some classes have only one teacher for one hundred pupils where they have to teach this class basic arithmetic, numeracy and literacy and this is a very big challenge. According to the Kenya National Union of Teachers (KNUT), an extra 100,000 teachers should be employed to reach the United Nations globally recommended teacher-pupil ratio of 1:35. This shortfall, coupled with poor facilities, inadequate learning materials and ineffective ways to measure learning outcomes, results in low quality education in many of Kenya's public schools.

Educationists have also expressed dismay at the deficiency of Early Childhood Development Centre (ECDE) teachers and the uncertainty about who should employ them. Whilst ECDE is EFA goal number one, which should have been mainstreamed in 2010, we have come to the expiry of EFA goals this year without attaining that goal. There are 3 million ECDE learners in the country requiring 70,000 teachers (KNUT, 2014). The number of pupils enrolled in primary school has been on the increase. According to projections of the UNESCO institute for statistics, if shortage of teachers persists amid the soaring of school enrolment, it could reach alarming levels by 2030 .

As we focus into the future of education in Kenya, we reiterate that the teaching profession will be critical in achieving quality education as articulated at the World Education Forum. We wish to restate for the umpteenth time that taking children to school is just the first step and therefore join Uwezo East Africa in asking the question, are our children learning? Answering this question will require a serious reorientation of the education system for us to achieve the desired results. For future planning, we need to see tangible actions that will address the situation, and ensure that children are in school and learning.

Apart from the employment of more teachers, the government has to create mechanisms for quality training for teachers, give them better salaries and classroom conditions. Kenya needs to migrate and employ modern teaching and learning tools. However, we first need to repackage the teacher training program so that it can give us better teachers for our primary schools. We cannot rely on the 1960 curriculum that was developed to meet the need of lack of teachers.

In Kenya, children learn to read by rote using a system of code emphasis that exalts alphabet memorization. Low literacy scores reflect reading trouble since reading is the foundation for other learning in the classroom. Wolf 2007 says that for learning to occur, it is imperative that reading takes place. Good readers learn better and score higher. As such, programs like the current Kenya Primary Math and Reading (PRIMR) should be encouraged and rolled out in the entire country. This program, an initiative of the USAID and the Government of Kenya, is aimed at laying the foundation to measurably improve the language and mathematics skills of learners by the end of Standard Two. If fully implemented, PRIMR will be a good attempt to move from a focus on providing access to a primary education for all children, to a focus on providing a quality education and learning.

Learning achievements have also consistently remained below the expected standards as schools are not regularly inspected. The inspection and supervision of basic education is still problematic because the sub county officials are not facilitated enough to reach each and every school. As provided for in the Constitution and the Basic Education Act, 2013, MoEST should move a step further to ensure quality delivery in our primary schools. The established Standards and Quality Assurance Council should supervise and oversee curriculum implementation and delivery. The cabinet secretary should monitor policies on quality in basic education. The Ministry should also build capacity for teachers, and guarantee that all education facilities and institutions are up to date. This with clear action plans and timelines will form a core part of the reform process towards delivery of quality basic education.

\section{CONCLUSION}

There was an emphasis on educational expansion that took place during the post-independence era in Kenya. The rationale for this improvement was to enhance the role of education in national development. However, this was not complemented by programmes that targeted quality improvement. The result of this has been poor quality of basic education which continues to affect Kenyan learners.

This paper has outlined how Kenya's past initiatives at increasing access have negatively impacted on the provision of quality basic education. While examining the current situation, this paper has argued that in shaping education for the future, efforts to expand enrolment must be accompanied by policies to enhance educational quality at all levels. 
Quality education and learning therefore should be one of the key areas of focus in the development of education for the future and the post 2015 agenda in Kenya.

\section{REFERENCES}

[1] Achola, P.W. and Pillai V.K. (2000). Challenges of primary education in developing countries: Insights from Kenya. Aldershot: Ash gate.

[2] Amutabi M. (2003). Political interference in the running of education in post-independence Kenya: A critical retrospection. International Journal of Educational Development.

[3] Bogonko S.N. (1992). A History of Modern Education in Kenya (1895 - 1991). Nairobi: Evans Brothers (K) Ltd.

[4] Elimu Yetu/Action Aid Kenya. (2004). Monitoring of the Free Primary Education and Establishing the Unit Cost Primary Education in Kenya.

[5] Eshiwani, G.S. (1993). Education in Kenya since Independence. Nairobi: East African Publishers.

[6] MoEST \& UNESCO (2005). Challenges of Implementing Free Primary Education in

[7] Kenya: Assessment Report. Nairobi: UNESCO, Nairobi Office.

[8] Okwach, A. and Abagi O. (2005). Schooling, Education and Underdevelopment. Nairobi: Own and Associates Ltd.

[9] Republic of Kenya. (2013). The Education Act. Nairobi: Government Printer.
[10] Republic of Kenya. (2010). The Constitution of Kenya. Nairobi: The Attorney General.

[11] Republic of Kenya. (1999). Comprehensive Education Sector Report.

[12] Republic of Kenya. (1988). Report of the Presidential Working Party on Education and Manpower Training for the Next Decade and Beyond. Nairobi: Government Printer.

[13] Republic of Kenya. (1965). Sessional Paper No 1 of 1965 on African socialism and its application to planning in Kenya. Nairobi: Government Printer.

[14] Republic of Kenya. (1964). Kenya Education Commission Report (The Ominde Report) Nairobi: Government Printer

[15] Sifuna, D.N. and Oanda I.O. (2014). Historical and Contemporary Trends in the Development of Education in Kenya. Nairobi: Jomo Kenyatta Foundation.

[16] Sifuna, D. N. and Otiende E. (1994). An Introductory History of Education. Nairobi: Nairobi University Press Nairobi.

[17] Sifuna, DN. (1990). Development of Education in Africa: The Kenyan Experience. Nairobi: Nairobi University Press.

[18] Uwezo. (2014).Are Our Children Learning? Literacy and Numeracy across East Africa 2013. Nairobi: Uwezo East Africa at Twaweza.

[19] World Bank. (2013). Education Statistics: Data by Country. Retrieved from http://www.worldbank.org/country/Kenya on $22 / 02 / 2015$

[20] Wolf, M. (2007). Proust and the Squid: The Story and Science of the Reading Brain. HarperCollins. 